\title{
Will farmland transfer reduce grain acreage? Evidence from Gansu province, China
}

\author{
Ying Liu \\ College of Pastoral Agriculture Science and Technology, Lanzhou University, \\ Lanzhou, China and \\ State Key Laboratory of Grassland Agro-ecosystems, Lanzhou University, \\ Lanzhou, China \\ Chenggang Wang \\ Department of Agricultural and Applied Economics, Texas Tech University, \\ Lubbock, Texas, USA, and \\ Zeng Tang and Zhibiao Nan \\ College of Pastoral Agriculture Science and Technology, Lanzhou University, \\ Lanzhou, China and \\ State Key Laboratory of Grassland Agro-ecosystems, Lanzhou University, \\ Lanzhou, China
}

\begin{abstract}
Purpose - The purpose of this paper is to examine the impacts of farmland renting-in on planted grain acreage. Design/methodology/approach - A survey data of five counties were analyzed with the two-stage ordinary least squares model.

Findings - Households renting-in land trended to plant more maize, and the more land was rented by a household the more maize was planted, while wheat acreage showed non-response to farmland renting-in.

Practical implications - Overall, the analysis suggests that policy makers should be prepared for different changing trends of grain crop acreage across the nation as farmland transfer continues. Future research should pay attention to the effect of farmland transfer on agricultural productivity and rural household income growth. Originality/value - As the Chinese Government is promoting larger-scale and more mechanized farms as a way of protecting grain security, it is important to understand whether farmland renting-in will reduce planted grain acreage. This study provides empirical evidence showing the answer to that question may differ across different regions and depend on the particular grain crop in question.
\end{abstract}

Keywords Food security, Crop choice, Farmland rental market, Farmland transfer, Grain security,

Instrumental variable

Paper type Research paper

\section{Introduction}

With the largest population and grain consumption in the world, China has made great strides in improving agricultural productivity, allowing the country to feed 22 percent of the world's population with less than 9 percent of the world's arable land (Hubacek et al., 2007; Zhang, Cui and Zhang, 2014; Jiao et al., 2016). However, population growth and declining arable land continue challenging food security (Anderson and Strutt, 2014; Unnevehr and Hoffmann, 2015;

(c) Ying Liu, Chenggang Wang, Zeng Tang and Zhibiao Nan. Published by Emerald Publishing Limited. This article is published under the Creative Commons Attribution (CC BY 4.0) licence. Anyone may reproduce, distribute, translate and create derivative works of this article (for both commercial and non-commercial purposes), subject to full attribution to the original publication and authors. The full terms of this licence may be seen at http://creativecommons.org/licences/by/4.0/legalcode

This work was funded by the Chinese Center for Strategic Research of Grassland Agriculture Development (SRGAD).

Received 21 April 2017 Revised 10 August 2017 14 November 2017 Accepted 19 November 2017
Farmland transfer 
CAER 10,2

Zhang et al., 2016; Li et al., 2017). To ensure grain security, the Chinese Government has been pursuing a self-sufficiency policy aimed at domestic production of 95 percent of the wheat, rice, and maize demand (Rada et al., 2015; Zhuo et al., 2016). Besides, the Chinese Central Government's "First Document" in 2016 and 2017 placed grain security as one of the government's top priorities, and put forward farmland consolidation as one of the key strategies to achieve food security targets. Although small family-operated farms have been driving productivity growth for several decades, new growth models are needed to match the food demand of an increasingly urbanized population (Tan et al., 2008; Feng, 2008; Chen et al., 2011). Deepening rural farmland market reforms is considered as a promising approach to address the food security challenges facing China (Zuo et al., 2015; Rada et al., 2015; Wang et al., 2017).

For this purpose, the government has openly encouraged farmland transfer, resulting in significantly growing of farmland rental market in rural China. The release of surplus labor from rural areas to urban industrial sectors also contributed to this growth (Kung, 2002; Zhang, 2008; Feng et al., 2010; Gao et al., 2012; Ito et al., 2016). Only 5.2 percent of contracted farmland in China was transferred in 2007, but this ratio rose to 33.3 percent by the end of 2015 (Cheng, 2009; Ministry of Agriculture of the People's Republic of China, 2016).

The acceleration of farmland rental markets has important implications for China's food security by improving agricultural productivity (Deininger, 2003; Feng et al., 2010). Lots of studies from China found that households renting land achieved higher allocative efficiency and technical efficiency than those without (Lohmar et al., 2001; Carter and Yao, 2002; Feng, 2008). Tan et al. (2006) showed that the development of land rental markets may reduce fragmentation, consequently improve China's agricultural productivity. Further farmland transfer can also release more surplus farm labor into off-farm labor markets, and the resulting occupational diversification can boost income and reduce inequality in rural areas (Masterson, 2007; Jin and Jayne, 2013). In an empirical analysis based on 8,000 households in China's nine leading agricultural provinces, Jin and Deininger (2009) found that the development of land rental markets greatly improved rural households' income from non-agricultural sectors. The positive impacts of farmland rental markets and farmland consolidation on agricultural productivity were also proved by studies in Northern Ethiopia, Kenya, and Europe (Crecente et al., 2002; Benin et al., 2005; Pašakarnis and Maliene, 2010; Jin and Jayne, 2013; Lisec et al., 2014; Hartvigsen, 2014).

On the other hand, farmland rental markets may have some negative impacts on agricultural production and food security. Conversion of farmland to non-farm uses can reduce land resources for food production (Chen et al., 2014; Liu et al., 2014). Besides, there is a large body of empirical evidence that yields decline as farm size grows, and an increasing evidence of an inverse U-shaped relationship between farm size and yields caused by rising wage rates in China and other Asian countries, so farmland transfer does not necessarily bolster food security (Rada et al., 2015; Wang, Chen, Gupta and Huang, 2015; Otsuka et al., 2016).

Farmland transfer may also lead to changes in crop mix - for example, it may result in a substitution of cash crops for grains - which bears important implications for China's grain food security policy. Grain crops are generally considered to be relatively land-intensive crops (Huang and Chen, 1999). Farmers that specialize more in grain crops are therefore more likely to rent additional land than farmers specializing in less land-intensive crops. On the other hand, well-functioning land rental markets transfer land from low-productive to relatively high-productive farmers (Otsuka, 2007; Ma et al., 2017). With the development of farmland rental markets, more and more farmland in China is now used for non-grain production since planting grain crops has relatively low earnings (Zhao et al., 2017). Moreover, farmland renting-in often comes with enlarging of farm size and reducing of farmland fragmentation, which favors the mechanized farming, and these changes may play significant roles in agricultural production, including agricultural productivity and grain acreage, and then make effects on food security. In addition, households show different behaviors on agricultural investments between contracted land and rented-in land (Gao et al., 2012; Muraoka et al., 2015), 
which may also make effects on determining households' crop choice. In fact, some surveys indeed showed that farms renting-in land preferred to plant high profitable cash crops (Li and Gao, 2013; Huang, 2014; Zhang, Qu and Wei, 2014; Zhang, 2016). Besides, Yi and Cheng (2010) found that in Zhejiang and Hebei provinces, farms with leased land planted a larger portion of their farmland to non-grain crops than those without leased land. However, Zhang and $\mathrm{Du}$ (2015) found a negative relation between the percentage of non-grain crop area and farm size - the percentage of non-grain areas was relatively high before reaching the 50-mu threshold, and starts dramatically declining afterwards. This dispute indicates that the effects of farmland renting-in are different across regions. The Central Government of China is promoting farmland transfer and increasing farming scale as a way of protecting grain food security (Rada et al., 2015), while few studies have examined the impacts of farmland renting-in on grain acreage, and these scanty studies on this issue mainly focused on eastern coastal areas and central plain areas of China, with little attention on backward areas in Western China. Therefore, it is important to understand how farmland renting-in affects grain crop acreage.

The purpose of this paper is to examine: how farmland renting-in affects crop choice and grain acreage; and whether farmland renting-in affects the acreage of different grains differently. Our econometric analysis is based on a survey conducted in 2015 covering 705 households in 25 villages of Gansu province. We find that farmland renting-in has significantly boosted planted grain crop area. But individual grain acreage responds differently to land transfers. While wheat acreage is little affected by land renting-in, maize acreage responds to land renting-in quite significantly. We rationalize these differences in the context of farm household decisions and policy incentives.

The rest of paper is organized as follows. The next section describes the study area and survey methods. Section 3 presents the variables and two-stage ordinary least squares (2SLS) model employed. In Section 4, the results are reported. Discussion and conclusion are offered in the final section.

\section{Study area and data}

This study selected five counties in Gansu province, China (Figure 1). Gansu province is located in the upstream of Yellow River basin, where the Loess Plateau, Qinghai-Tibet Plateau, and Inner Mongolian Plateau join one another. The land area of Gansu province is $42.58 \times 10^{4}$ square kilometers, about 4.7 percent total area of China. It is one of the major grain producing provinces in Northwestern China. In 2015, the planted grain crops area is 2,850 hectares, accounting for 2.5 percent of national level (National Bureau of Statistics of the People's Republic of China, 2015). In addition, Gansu province is one of the less developed region of China with relative poor agricultural production conditions and a low level of urbanization. With the implementation of the "land conversion from farmland to forest or grassland" policy, Gansu's farmland has shrunk significantly. In particular, grain acreage has experienced a sharp decline from 70.07 percent in 2010 to 67.72 percent in 2014 (Editorial Board of Gansu Development Yearbook, 2012, 2014 and 2016).

Gansu province has also made great progresses in farmland transfer. About 16.1 percent of contracted farmland in Gansu province was transferred by the end of March 2014 (Liang and Ma, 2014), and 18.87 percent (measured by rented-in land area) of contracted farmland in studied areas was transferred, and 34.18 percent of households involved in farmland transfer by the end of 2013, according to our survey.

The survey was conducted from April to September, 2015. Five counties were selected using the sampling methods of Huang et al. (2012). Specifically, all 86 counties or districts in Gansu province were sorted from high to low by the average total industry output value per capita in 2012, an indicator of the economic development level. The counties were then divided into five groups, and a county was randomly chosen from each group to represent that group. Within each county, five townships were randomly chosen, generating totally 25 townships in 


\section{CAER}

10,2

\section{0}

Figure 1.

Location of 25 sample townships

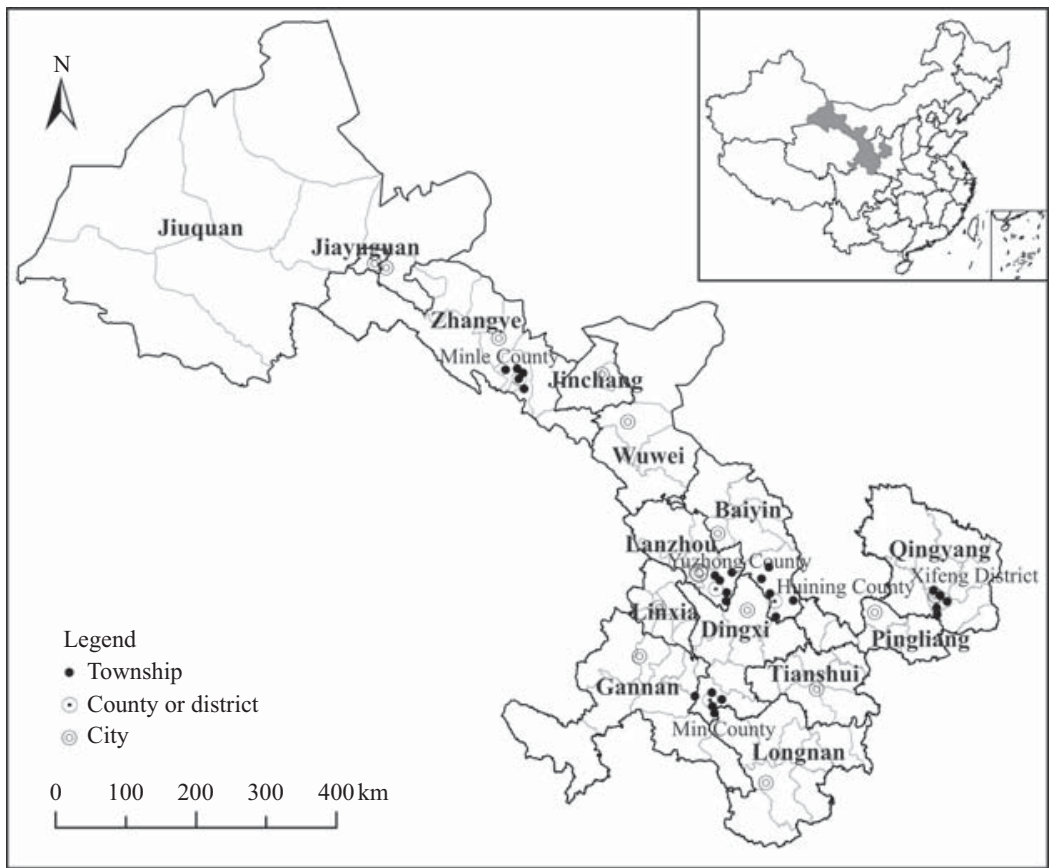

the sample. The five selected counties are Xifeng District, Yuzhong County, Minle County, Huining County, and Min County. Their average total industry output value per capita in 2012 was 23,691 yuan, 8,656 yuan, 4,453 yuan, 1,447 yuan, and 778 yuan, respectively (Table I). Furthermore, one village was randomly selected from each township, yielding 25 villages in the sample. Finally, we interviewed 20-30 rural households from each village, and the survey was conducted with the household head. Totally 705 households were surveyed. The interview was conducted by students of Lanzhou University with proper training. They were randomly dropped off in the front door of a household to conduct the interview. The questionnaire contains demographic information, planting and breeding situation, inputs and outputs of crops, farmland types and area, farmland lease situations, and willingness to transfer farmland. After excluding from the sample the households that rented out all land and did not grow any crops, we are left with a sample of 603 households for the ensuing analysis.

\section{Variables and estimation model}

\subsection{Variables}

The two main grain crops in rural areas of Western China are wheat and maize, which take up 39.83 percent of the total planted area in our study. Three dependent variables are defined as

\begin{tabular}{llcccc}
\hline Sample counties & City & $\begin{array}{c}\text { Average industrial output } \\
\text { value per capita (yuan) }\end{array}$ & Group & $\begin{array}{c}\text { Number of } \\
\text { households }\end{array}$ & $\begin{array}{c}\text { Number of households } \\
\text { included in analysis }\end{array}$ \\
\hline Xifeng District & Qingyang & 23,691 & 1 & 144 & 141 \\
Yuzhong County & Lanzhou & 8,656 & 2 & 157 & 115 \\
Minle County & Zhangye & 4,453 & 3 & 123 & 78 \\
Huining County & Baiyin & 1,447 & 4 & 132 & 128 \\
Min County & Dingxi & 778 & 5 & 149 & 141 \\
& & & & &
\end{tabular}

Table I.

Sample structure 
representative of grain acreage shares: wheat acreage share (the percentage of planted wheat area to total planted area on a farm), maize acreage share (the percentage of planted maize area to total planted area on a farm), and the sum of the two (grain acreage share).

The key explanatory variable is rented-in land share, defined as the percentage of rented-in farmland on a farm, where the total land area is equal to a households' contracted farmland area plus rent-in and minus rent-out. Previous studies mainly examined whether households plant non-grain crops on rented-in farmland or not, and how planted non-grain crops area on rented-in farmland changes with the increasing of rented-in farmland (Yi and Cheng, 2010; Zhang and Du, 2015; Zhang and Jiang, 2016). This study assumes that given the same farm size and plot size, not only the fact that whether a household rent-in land or not will affect crop choice, the relative size of rented-in farmland area to contracted land area and the component of operating farmland may also play roles in determining crop choice of a household. Thus, rented-in land share is employed as the key explanatory variable for it not only measures whether household rented-in land or not, but also contains information on the relative size of rented-in area land to contracted land area, and the component of operating land of a farm. We expect this variable to be negatively correlated with our dependent variables, based on conclusions of previous studies (Yi and Cheng, 2010; Zhang and Jiang, 2016).

According to previous studies, control variables in our model include farmer characteristics, household characteristics, crop profitability, agricultural policy, and county dummies (Feng and Heerink, 2008; Feng et al., 2010; Yi and Cheng, 2010; Huang et al., 2012; Che, 2016). Farmer characteristics include household head age, age square, education, and health condition. Household characteristics include family labor ratio, off-farm income ratio, and per capita land area. Crop profitability includes wheat profit per mu and maize profit per mu. These are factors directly related to agricultural production. Policy variables include grain subsidies received, land reallocation, and land transfer policy, which exhibit sizable variation across our sample. County dummies were included to control for cross-county differences in climate, soil, and economic conditions. Land reallocation and land transfer policy were employed as instrumental variables (IVs), given that they affect land renting-in but not crop choice.

Table II reports the descriptive statistic of dependent variables and explanatory variables. The average wheat, maize, and grain acreage shares are 19.65, 22.18, and 41.83 percent, respectively. The average rented-in land share is 4.80 percent in the study area, indicating a primary stage of farmland transfer in Gansu province. Household heads have an average age of 51.03 years old, which is a little higher than that of national level (46.75 years old) in a survey conducted in 2003 (Che, 2016) and close to that of in North Henan province (50.21) in 2009 (Yan and Huo, 2016). The average educational year of household head is 6.04 years which is lower than that of North Henan province (7.50 years) in the survey of Yan and Huo (2016) in 2009, indicating a poor education condition in Northwestern China. More than 90 percent of household heads are in general or good health condition. Households have an average family labor ratio of 66.24 percent and average off-farm income ratio of 68.00 percent which is very close to the data (65.68 percent) in Wang et al.'s (2017) study on Chongqing in 2012 and 2014, suggesting that off-farm income has become a critical income source to households in the study area. The average per capita land area is $2.51 \mathrm{mu}$ which is a little higher than that of whole country $(1.77 \mathrm{mu})$ in 2003 (Che, 2016). This variable has a very small minimum value of $0.06 \mathrm{mu}$ per capita due to severe mismatch between contracted farmland area and family size to some households. Some villages have not reallocated their farmland since the starts of Household Contracted Responsibility System, while family size of some households in these villages has enlarged by a few times. This finally resulted in the severe mismatch between contracted farmland area and family size. The average profit per mu of wheat and maize are $-0.49 \times 10^{3}$ yuan and $-0.24 \times 10^{3}$ yuan, respectively. The negative values and large 
CAER 10,2

\section{2}

Table II.

Descriptive statistics of variables used in analysis

\begin{tabular}{|c|c|c|c|c|}
\hline Variable & Mean & $\mathrm{SD}$ & Min. & Max. \\
\hline \multicolumn{5}{|l|}{ Dependent variables } \\
\hline Wheat acreage share $(\%)$ & 19.65 & 24.66 & 0 & 100 \\
\hline Maize acreage share $(\%)$ & 22.18 & 28.07 & 0 & 100 \\
\hline Grain acreage share $(\%)$ & 41.83 & 35.94 & 0 & 100 \\
\hline \multicolumn{5}{|l|}{ Explanatory variables } \\
\hline Rented-in land share (\%) & 4.80 & 14.88 & 0 & 98.60 \\
\hline \multicolumn{5}{|l|}{ Farmer characteristics } \\
\hline Household head age & 51.03 & 11.08 & 22 & 81 \\
\hline $\mathrm{Age}^{2}$ & $2,726.53$ & $1,146.78$ & 484 & 6,561 \\
\hline Education (years) & 6.04 & 3.91 & 0 & 16 \\
\hline General health condition, general $=1$; others $=0$ & 0.18 & 0.39 & 0 & 1 \\
\hline Good health condition, good $=1$; others $=0$ & 0.73 & 0.44 & 0 & 1 \\
\hline \multicolumn{5}{|l|}{ Household characteristics } \\
\hline Family labor ratio (\%) & 66.24 & 22.95 & 0 & 100 \\
\hline Off-farm income ratio (\%) & 68.00 & 32.48 & 0 & 100 \\
\hline Per capita land area (mu) & 2.51 & 2.20 & 0.06 & 16.50 \\
\hline \multicolumn{5}{|l|}{ Agricultural production characteristics } \\
\hline Wheat profit per $\mathrm{mu}\left(\times 10^{3}\right.$ yuan) & -0.49 & 0.45 & -1.17 & 1.18 \\
\hline Maize profit per mu ( $\times 10^{3}$ yuan) & -0.24 & 0.77 & -1.65 & 2.45 \\
\hline \multicolumn{5}{|l|}{ Political characteristics } \\
\hline Grain subsidies, yes $=1$; others $=0$ & 0.80 & 0.40 & 0 & 1 \\
\hline Land reallocation & 1.14 & 0.70 & 0 & 3 \\
\hline Land transfer policy, yes $=1 ;$ no $=0$ & 0.58 & 0.49 & 0 & 1 \\
\hline \multicolumn{5}{|l|}{ County dummies } \\
\hline Xifeng, household in Xifeng District $=1$; others $=0$ & 0.23 & 0.42 & 0 & 1 \\
\hline Yuzhong, household in Yuzhong County $=1$; others $=0$ & 0.19 & 0.39 & 0 & 1 \\
\hline Minle, household in Minle County $=1$; others $=0$ & 0.13 & 0.34 & 0 & 1 \\
\hline Huining, household in Huining County $=1$; others $=0$ & 0.21 & 0.41 & 0 & 1 \\
\hline
\end{tabular}

Notes: $1 \mathrm{mu}$ is $1 / 15$ hectares; age ${ }^{2}$ is the square of household head age; education is education condition of household head; health condition is the health condition of household head; family labor ratio is equal to number of labors over family size, and family labors including all family members who ware able-bodied, not in school and between 16 and 65 years old (Huang et al., 2012); off-farm income ratio is equal to off-farm income over total income; per capita land area is equal to contracted farmland over family size; wheat profit per mu and maize profit per mu are average values of households for each village; profit $=$ price $\times$ yield-production cost (including labor cost, machine cost, seed cost, water cost, fertilizer cost, chemical cost and all other fees for material and service purchased for wheat or maize production), without including subsidies, and labor cost includes the cost of hired labor and family labor, machine cost includes the cost of rented machines and machines owned by households; grain subsidies is the answer of household to the question that "Have your family received grain subsidies last year?"; land reallocation is the frequency of farmland that has been reallocated by any kind of reallocation, since the start of Household Contracted Responsibility System; land transfer policy is the answer of household to the question that "Do you know that the Chinese Central Government are encouraging farmland transfer?"

variation of these two variables are mainly due to the high labor cost (cost 7.41 days per mu in wheat production, 10.54 days per mu in maize production, and 88.79 yuan per day in average of our survey) and large variation on labor demand to grow these two crops between households using machine and those without using machine, respectively. At the policy level, 80 percent of household think that they received the grain subsidies, and 58 percent of households know that government is promoting farmland transfer. Frequency of farmland reallocation has an average value of 1.14 times and 20 percent of villages did not experience any land reallocation, while Henan province has an average farmland reallocation frequency of 2.69 times in a survey conducted in 2009 (Yan et al., 2014), suggesting a relative stable land tenure in the study area. 
Our econometric model examines the impacts of land renting-in on planted grain acreage.

The key econometric issue is the potential simultaneity bias arising from omitted variables that simultaneously affect farmland transfers and crop choice.

The IV estimation technique is a commonly adopted solution to the endogeneity problem, and many previous studies used IVs to overcome the endogeneity bias (Levitt, 1997; Hoxby, 2000; Acemoglu et al., 2001; Satyanath and Sergenti, 2004; Ruseski et al., 2014). It transfers correlational relationships among dependent variables and independent variables into causal relationships (Heckman, 2000; Burgess et al., 2017). Thus, a 2SLS model with IVs was selected in this study.

To yield valid results, instruments must predict the exposure, must affect the outcome only through the exposure, and must not share unmeasured common causes with the outcome (Nguyen et al., 2016). Lots of studies found that land tenure security has great impacts on farmland transfer (Li et al., 2009; Yi and Cheng, 2010), and land reallocation reflects the security of land tenure. Land reallocations have served, and at some places still serve, as a substitute for land rental markets (Deininger and Jin, 2005). The more land reallocations have taken place, the lower likelihood of households to transfer their land. Hence, land reallocations have a direct impact on land transfer. Besides, government's encouragement policies on farmland transfer may also promote farmland transfer behaviors of rural households. Variables on land reallocation and land transfer policy determine the demand and supply of farmland rental market in an area. In addition, a rural household's crop choice and land portfolio decisions should not be directly affected by such transaction costs. Thus, land reallocation and land transfer policy satisfy the condition of instruments, and were employed as IVs for a household's farmland lease decision in our model.

Our basic econometric model is written as follows:

$$
y_{i c}=\alpha_{0}+\alpha_{1} R_{i c}+X^{\prime} \mu+D^{\prime} \varphi+u_{i c}
$$

where $y_{i c}$ is wheat, maize, or grain acreage shares for a household $i$ in county $c$; $R_{i c}$ is rented-in land share for a household $i$ in county $c ; X^{\prime}$ is a vector of exogenous variables including farmer characteristics, household characteristics, crop profitability, and grain subsidies; $D^{\prime}$ is a vector of county dummies; and $u_{i c}$ is the random disturbance term which is assumed to be independently and identically distributed; $\alpha_{0}, \alpha_{1}, \mu$, and $\varphi$ are parameters to be estimated.

The first stage can be expressed by the following equation:

$$
R_{i c}=\beta_{0}+Z^{\prime} \gamma+X^{\prime} \theta+D^{\prime} \omega+\varepsilon_{i c}
$$

where $Z^{\prime}$ is the vector of IVs including land reallocation and land transfer policy; $X^{\prime}$ is the vector of exogenous variables; $D^{\prime}$ is a vector of county dummies; and $\varepsilon_{i c}$ is the random disturbance term; $\beta_{0}, \gamma, \theta$, and $\omega$ are parameters to be estimated.

\section{Results}

\subsection{First-stage regression}

Estimation results of Equation (2) are presented in Table III. Overall the two IVs are each correlated with the key endogenous variable, rented-in land share, at 1 percent level. Land reallocation is negatively correlated with rented-in land share of households, and its coefficient is -6.398 . This result is consistent with the study of Li et al. (2009) and the study of Yi and Cheng (2010), suggesting that unstable land tenure will prevent farmland transfer. Land transfer policy is positively correlated with rented-in land share of households, and its coefficient is 6.994. The active effects of government policy are reflected by these results. 
CAER

10,2

Table III.

First-stage regression results

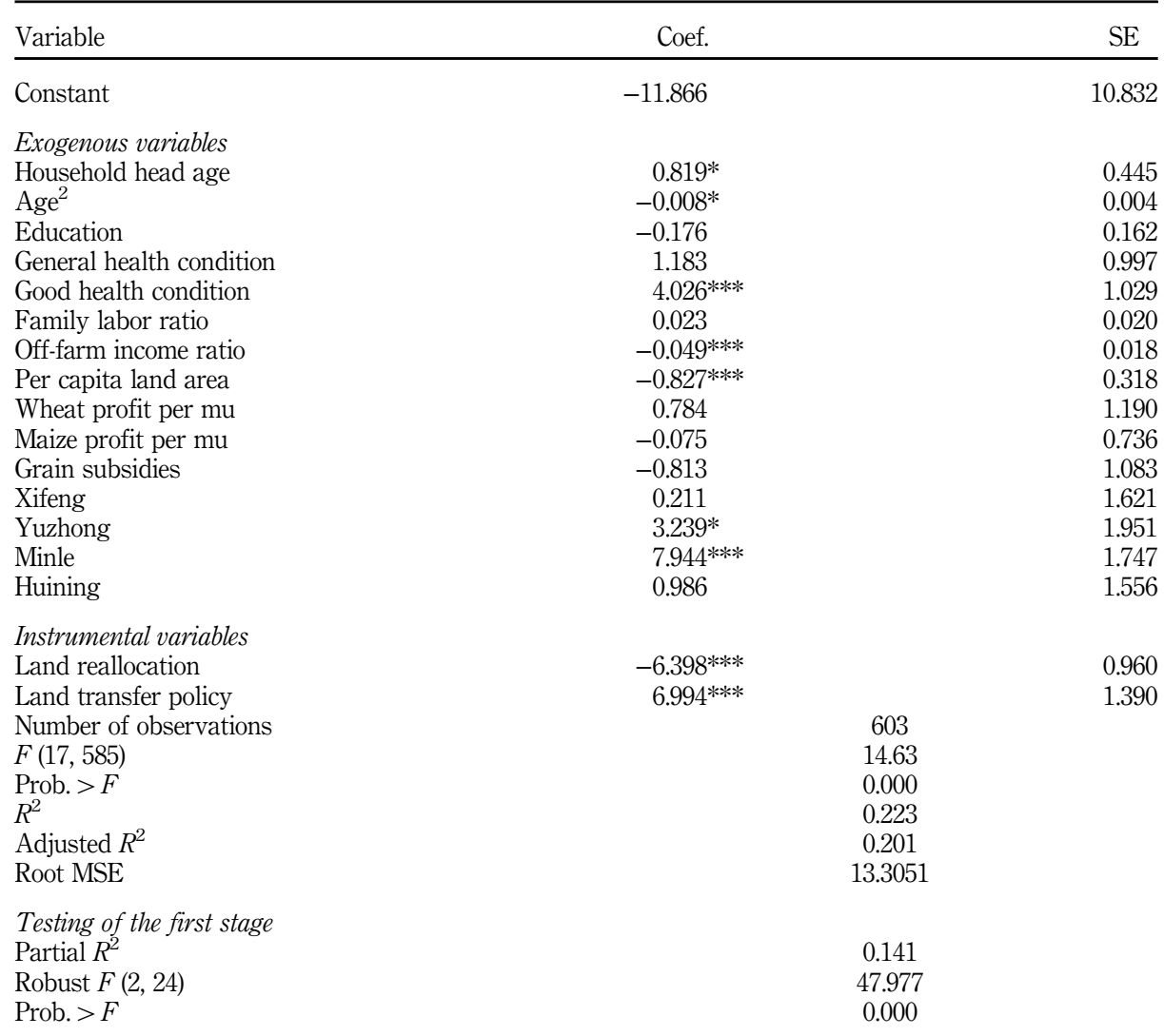

Notes: The standard errors are robust standard errors clustered at village level. ******Statistically significant at 10, 5 and 1 percent levels, respectively

A number of tests were run to formally test the power of the instruments. The partial $R^{2}$ statistic measures the correlation between our endogenous variable and instruments after partialling out the impact of independent variables (Bound et al., 1995). The partial $R^{2}$ in our model is 0.141 , indicating a medium level of explanatory power of the instruments. The $F$-statistic (47.977) exceeds the empirical value of 10, suggesting that reliable inference can be drawn from 2SLS estimators (Stock et al., 2002). Overall the set of instruments in our regression is fairly reliable and strong.

A few coefficients in the first-stage regression can help understand a farm household's decision of renting farmland. Rented-in farmland share seems to depend on the household head's characteristics. The coefficients on household head age and age square, respectively, are 0.819 and -0.008 , and both of them are significant at 10 percent level. This indicates an inverted U-shaped relation between household head age and households' rented-in land share - the rented-in land share increases with age up to a peak point of 53.21 years old, after which it starts declining. The coefficient of the household head's health condition (good health condition) is 4.03 and significant at 1 percent level. Farming is labor intensive, and the household head frequently is the main labor supplier in rural China. Good health seems to boost the household head's ambition to expand the farm. 
Among household characteristics, the ratio of off-farm earnings to the household's total income is negatively correlated with the rented-in land share at 1 percent level, with a coefficient of -0.049 and standard error of 0.018 . This suggests that 1 percentage point increase in off-farm income ratio may result in a 0.049 percentage point decrease in rented-in land share. This is likely because off-farm employment tends to have a higher return to labor than farm work.

\subsection{Second-stage regression}

Table IV reports the 2SLS estimation results of Equation (1). Overall rented-in land share has no significant impact on wheat acreage share $(p>0.1)$, but boosts planted maize acreage $(p<0.01)$. The total grain acreage also increases with rented-in land share $(p<0.05)$, which is likely to reflect the positive response of maize acreage share to farmland renting-in. The irresponsiveness of wheat acreage to farmland renting-in is likely due to the low profitability of growing wheat in China - the average profit per mu of wheat is -489 yuan, and the average profit per mu of maize is -237 yuan without subsidy (Table I). In the regions we surveyed, wheat is mostly grown as a subsistence crop in small patches of land (Yuan et al., 2010), and only has $0.55 \mathrm{mu}$ per capita of land planted to wheat in average of our sample. The significant coefficient of 0.774 in the maize and 1.063 in all grain regression indicates that 1 percentage point increase in rented-in land share leads to 0.774 percentage point increase in maize acreage share, and 1.063 percentage point increase in grain acreage share. In addition to its relative profitability, maize is widely used as fodder,

\begin{tabular}{|c|c|c|c|c|c|c|}
\hline \multirow[b]{2}{*}{ Independent variables } & \multicolumn{2}{|c|}{ Wheat } & \multicolumn{2}{|c|}{ Maize } & \multicolumn{2}{|c|}{ Grain crops } \\
\hline & Coef. & SE & Coef. & SE & Coef. & SE \\
\hline Constant & -23.494 & 18.278 & 13.503 & 8.549 & -9.992 & 16.881 \\
\hline $\begin{array}{l}\text { Key variable of interest } \\
\text { Rented-in land share }\end{array}$ & 0.289 & 0.271 & $0.774^{* * * *}$ & 0.299 & $1.063^{* *}$ & 0.496 \\
\hline \multicolumn{7}{|l|}{ Exogenous variables } \\
\hline Household head age & 0.771 & 0.708 & -0.616 & 0.513 & 0.155 & 0.759 \\
\hline $\mathrm{Age}^{2}$ & -0.006 & 0.007 & 0.006 & 0.005 & -0.001 & 0.008 \\
\hline Education & -0.054 & 0.264 & 0.229 & 0.254 & 0.175 & 0.266 \\
\hline General health condition & -1.906 & 4.409 & -1.894 & 2.911 & -0.012 & 5.606 \\
\hline Good health condition & -0.683 & 3.391 & -2.941 & 3.446 & -3.624 & 5.139 \\
\hline Family labor ratio & -0.027 & 0.032 & -0.009 & 0.029 & -0.036 & 0.047 \\
\hline Off-farm income ratio & $0.104 * * *$ & 0.041 & 0.047 & 0.038 & $0.151^{* *}$ & 0.070 \\
\hline Per capita land area & 0.026 & 0.846 & 0.679 & 0.687 & 0.653 & 1.367 \\
\hline Wheat profit per mu & $7.843^{*}$ & 4.578 & $-9.123 * * *$ & 2.243 & -1.280 & 4.107 \\
\hline Maize profit per mu & $-6.814^{* * * *}$ & 1.546 & $22.208 * * *$ & 3.040 & $15.394 * * *$ & 3.459 \\
\hline Grain subsidies & $4.374^{*}$ & 2.248 & 2.525 & 3.716 & $6.898^{*}$ & 3.966 \\
\hline Xifeng & $32.998 * * *$ & 6.958 & 14.188 & 4.636 & $47.185^{* * * *}$ & 5.796 \\
\hline Yuzong & $9.945^{*}$ & 5.855 & $38.642 * * *$ & 4.596 & $48.587^{* * * *}$ & 9.844 \\
\hline Minle & $12.457^{* * *}$ & 5.270 & $-11.637^{*}$ & 6.458 & 0.820 & 9.920 \\
\hline Huining & $8.329 *$ & 18.278 & $36.108^{* * * *}$ & 4.394 & $44.437^{* * * *}$ & 6.226 \\
\hline Number of observations & \multicolumn{2}{|c|}{603} & \multicolumn{2}{|c|}{603} & \multicolumn{2}{|c|}{603} \\
\hline Wald $\chi^{2}$ value & \multicolumn{2}{|c|}{$1,020.71$} & \multicolumn{2}{|c|}{$1,295.63$} & \multicolumn{2}{|c|}{$2,289.48$} \\
\hline Prob. $>\chi^{2}$ & \multicolumn{2}{|c|}{0.000} & \multicolumn{2}{|c|}{0.000} & \multicolumn{2}{|c|}{0.000} \\
\hline$R^{2}$ & \multicolumn{2}{|c|}{0.311} & \multicolumn{2}{|c|}{0.449} & \multicolumn{2}{|c|}{0.379} \\
\hline Root MSE & \multicolumn{2}{|c|}{20.447} & \multicolumn{2}{|c|}{20.824} & \multicolumn{2}{|c|}{28.303} \\
\hline
\end{tabular}

Notes: The standard errors are robust standard errors clustered at village level. *******Statistically significant at 10, 5 and 1 percent levels, respectively
Farmland transfer

285 
CAER 10,2 a commodity rather than a subsistence crop. Although wheat and maize are both row crops suitable for mechanized farming, maize seems to be a better choice for rented-in farmland.

Farmer characteristics, including the age, education, and health condition of household head, have no significant effect on crop choice and grain acreage. These results indicate that the crop and acreage choice for rural households mainly depends on the convenience of production, and the profit of a special crop, but not the household head's personal characteristics. Note that, the convenience of production means suitable for relative large-scale and mechanized farming among rural households. For example, a farm can grow $50 \mathrm{mu}$ grain crops without hiring labors, but impossible to grow 50 vegetables or flowers hiring labors.

Among variables of household characteristics, off-farm income ratio significantly increases the wheat acreage share (0.104) and total grain acreage share (0.151), but does not seem to affect maize acreage share. A 1 percentage point increase in off-farm income ratio leads to a 0.104 percentage point increase in planted wheat share, and 0.151 percentage point increase in planted grain crops share. Households with high off-farm income ratio tend to have less labor available for farming. Wheat as a less labor-demanding crop is certainly a popular choice for households with scarce family agricultural labor. In contrast, maize, as a commodity crop, demands a higher level of commitment from the household's laborers than wheat.

Wheat profit per mu has a positive correlation with wheat acreage share, and a negative correlation with maize acreage. The estimated coefficients (7.843 in wheat regression and -9.123 in maize regression) suggest that a 1,000 yuan increase in wheat profit per mu will lead to 7.843 percentage point increase in wheat acreage share, and 9.123 percentage point decrease in maize acreage share. Maize profit per mu has a negative effect on wheat acreage share, and a positive effect on maize acreage share. The significant positive response of total grain acreage to maize profit per mu is likely a result of mechanization, and large-scale planting of maize. The estimated coefficients (-6.814 in wheat regression, 22.208 in maize regression, and 15.394 in grain regression) suggest that a 1,000 yuan increase in maize profit per mu will reduce wheat acreage share by 6.814 percentage point, and boost maize acreage share by 22.208 percentage point and total grain acreage share by 15.394 percentage point.

Grain subsidies have a positive effect on wheat acreage share and on total grain acreage share. The estimated coefficients (4.374 in wheat regression and 6.898 in grain regression) suggest that a household receiving subsidies has 4.374 percentage point more farmland devoted to wheat than a household without, and 6.989 percentage point more to grain acreage share. All county dummies are statistically significant except Xifeng in the wheat analysis and Minle in the grain crops analysis, indicating noticeable differences in grain acreage shares across the counties likely due to climate, soil, and economic factors.

\section{Discussion}

Grain security is one of the top policy priority of Chinese Government (Wang, Wu and Sun, 2015; Jiang et al., 2017). As China continues deepening its reforms of the rural land rental markets, it is important to understand the implications of farmland transfer and consolidation for the nation's grain food security. Such implications need to be understood at the farm level by examining the farmer's crop choice and the incentives of growing grain crops. Unfortunately, few studies have examined these issues. This paper fills the gap by studying the impacts of a farmer's rented-in land share on grain acreage share. Our econometric model is identified with a set of instruments, which finally depends on the demand and supply of farmland transfer in the area.

The main finding of our analysis is that households renting-in land trended to plant more maize, and the more land was rented by a household the more maize was planted, 
while wheat acreage showed non-response to farmland renting-in. Our results are in stark contrast to a previous study conducted in Eastern China, which showed that farmland consolidation tends to encourage planting of non-grain crops and discourage planting of grain crops (Yi and Cheng, 2010). A possible explanation is that households in the eastern and central developed areas have higher opportunity costs to grow grain crops than those of in western economic backward areas. It resulted in that households in developed areas have stronger urge to grow cash crops with highly profitable than those of in backward areas. Moreover, poorer information flow and transportation $(\mathrm{Wu}, 2015 \mathrm{a}$; Zhang and $\mathrm{Lu}, 2016)$ in backward areas of Western China greatly reduced the anti-risk capability of households, compared with those in eastern and central developed areas. This leads to the fact that rural households in Western China bear higher risk to plant high profitable cash crops. Therefore, maize, as a crop with relative high profit (Wu, 2015b), low risk on yield and price (Dercon, 1996; Gale, 2013) and suitable for relative large-scale and mechanized farming among rural household (Perelman, 1972), becomes a popular crop among households renting-in land.

However, our findings are consistent with those from a national study conducted by Zhang and Du (2015), showing that farmland renting-in boosts planted grain acreage. Taken together, these findings suggest that the effects of farmland renting-in on grain crop acreage are likely to vary across regions. Policy makers should expect that the changing trends of grain crop acreage differ in different parts of the nation.

Our analysis also suggests that within the bundle of grain crops defined by the government, there could be differential acreage responses to farmland transfer. In our sample, wheat as a subsistence crop (Yuan et al., 2010) does not seem to be considered in a household's farmland renting-in, while the increasing commodification of maize makes it a strong crop choice for farmers with ambition to expand farm.

While these results may depict an optimistic picture as it relates to grain food security, they also suggest that productivity and profitability is at the heart of a farmer's cropping decision, as can be seen from the sharp contrast responses between wheat and maize acreage decisions to farmland renting-in. From a policy perspective, food security should seek to find the most effective way of improving profitability of grain crops. While the government has been granting large amount of subsidies to encourage farmers to grow grain crops, these programs are highly costly to the society and may not be the most effective way of promoting grain production.

Results of this study could provide some hints for understanding the role of farmland transfer in crop choice, and help policy maker to adapt some strategies to ensure food security. On the other hand, it is also worth noting that our results are based on a single-year data in one province, and some variation may exist among years and regions. Applying panel data methods to such data sets would reduce the impact of unobserved household and village heterogeneity that plagues simple cross-section analyses. Thus, a more robust research involving multiple years and regions is needed in further studies.

\section{Conclusion}

This study sheds light on the impacts of farmland renting-in on grain acreage. The 2SLS model with IVs was employed to solve the endogeneity problem of this study. The results indicate that households renting-in land trended to plant more maize, while wheat acreage showed non-response to farmland renting-in. Regarding to these results are contrast with the results of some other studies and two grain crops showed different responses to farmland renting-in in our study, the responses of grain crops to farmland transfer may differ across different regions and different grain crops. It is suggested that farmland transfer may be beneficial to China's grain self-sufficiency policy in some areas similar with Gansu province, but policy makers should be prepared for different changing trends of 
CAER 10,2 grain crop acreage across the nation as farmland transfer continues. Besides, productivity and profitability is at the heart of a farmer's cropping decision. Thus, more research is needed to examine whether farmland transfer improves the productivity of grain crops and rural household income.

\section{References}

Acemoglu, D., Johnson, S. and Robinson, J.A. (2001), “The colonial origins of comparative development: an empirical investigation”, American Economic Review, Vol. 91 No. 5, pp. 1369-1401.

Anderson, K. and Strutt, A. (2014), "Food security policy options for China: lessons from other countries", Food Policy, Vol. 49, pp. 50-58.

Benin, S., Ahmed, M., Pender, J. and Ehui, S. (2005), "Development of land rental markets and agricultural productivity growth: the case of Northern Ethiopia”, Journal of African Economies, Vol. 14 No. 1, pp. 21-54.

Bound, J., Jaeger, D.A. and Baker, R.M. (1995), "Problems with instrumental variables estimation when the correlation between the instruments and the endogenous explanatory variable is weak", Journal of the American Statistical Association, Vol. 90 No. 430, pp. 443-450.

Burgess, S., Small, D.S. and Thompson, S.G. (2017), "A review of instrumental variable estimators for Mendelian randomization", Statistical Methods in Medical Research, Vol. 26 No. 5, pp. 2333-2355.

Carter, M.R. and Yao, Y. (2002), "Local versus global separability in agricultural household models: the factor price equalization effect of land transfer rights", American Journal of Agricultural Economics, Vol. 84 No. 3, pp. 702-715.

Che, Y. (2016), "Off-farm employments and land rental behavior: evidence from rural China", China Agricultural Economic Review, Vol. 8 No. 1, pp. 37-54.

Chen, R.S., Ye, C., Cai, Y.L., Xing, X.S. and Chen, Q. (2014), "The impact of rural out-migration on land use transition in China: past, present land trend", Land Use Policy, Vol. 40 No. 4, pp. 101-110.

Chen, X.P., Cui, Z.L., Vitousek, P.M., Cassman, K.G., Matson, P.A., Bai, J.S., Meng, Q.F., Hou, P., Yue, S.C., Römheld, V. and Zhang, F.S. (2011), "Integrated soil-crop system management for food security", Proceedings of the National Academy of Sciences of the United States of America, Vol. 108 No. 16, pp. 6399-6404.

Cheng, X.H. (2009), "Effectively strengthen the management and services in farmland transfer", Management and Administration on Rural Cooperative, No. 1, pp. 6-11 (in Chinese).

Crecente, R., Alvarez, C. and Fra, U. (2002), "Economic, social and environmental impact of land consolidation in Galicia”, Land Use Policy, Vol. 19 No. 2, pp. 135-147.

Deininger, K. (2003), "Land markets in developing and transition economics: impact of liberalization and implications for future reform", American Journal of Agricultural Economics, Vol. 85 No. 5 , pp. 1217-1222.

Deininger, K. and Jin, S.Q. (2005), "The potential of land rental markets in the process of economic development: evidence from China”, Journal of Development Economics, Vol. 78, pp. 241-270.

Dercon, S. (1996), "Risk, crop choice, and savings: evidence from Tanzania”, Economic Development and Cultural Change, Vol. 44 No. 3, pp. 485-513.

Editorial Board of Gansu Development Yearbook (2012, 2014 and 2016), Gansu Development Yearbook, China Statistics Press, Beijing.

Feng, S.Y. (2008), "Land rental, off-farm employment and technical efficiency of farm households in Jiangxi province, China", NJAS, Vol. 55 No. 4, pp. 363-378.

Feng, S.Y. and Heerink, N. (2008), "Are farm households' land renting and migration decisions inter-related in rural China?”, NJAS, Vol. 55 No. 4, pp. 345-362. 
Feng, S.Y., Heerink, N., Ruben, R. and Qu, F.T. (2010), "Land rental market, off-farm employment and agricultural production in Southeast China: a plot-level case study", China Economic Review, Vol. 21 No. 4, pp. 598-606.

Gale, F. (2013), "Growth and evolution in China's agricultural support policies”, ERR-153, US Department of Agriculture, Economic Research Service, August.

Gao, L.L., Huang, J.K. and Rozelle, S. (2012), "Rental markets for cultivated land and agricultural investments in China”, Agricultural Economics, Vol. 43 No. 4, pp. 391-403.

Hartvigsen, M. (2014), "Land reform and land fragmentation in Central and Eastern Europe", Land Use Policy, Vol. 36 No. 1, pp. 330-341.

Heckman, J.J. (2000), "Causal parameters and policy analysis in economics: a twentieth century retrospective", Quarterly Journal of Economics, Vol. 115 No. 1, pp. 45-97.

Hoxby, C.M. (2000), "Does competition among public schools benefit students and taxpayers?", American Economic Review, Vol. 90 No. 5, pp. 1209-1238.

Huang, W. (2014), "The non-agricultural and the non-grain oriented risk and it's circumventions in agricultural land transfer", Contemporary Economic Management, Vol. 36 No. 8, pp. 39-43 (in Chinese).

Huang, J.K. and Chen, C.L. (1999), "Effects of trade liberalization on agriculture in China: commodity aspects”, Working Paper No. 43, The CGPRT Centre Working Paper Series, August.

Huang, J.K., Gao, L.L. and Rozelle, S. (2012), "The effect of off-farm employment on the decisions of households to rent out and rent in farmland in China", China Agricultural Economic Review, Vol. 4 No. 1, pp. 5-17.

Hubacek, K., Guan, D.B. and Barua, A. (2007), "Changing lifestyles and consumption patterns in developing countries: a scenario analysis for China and India", Futures, Vol. 39 No. 9, pp. 1084-1096.

Ito, J., Bao, Z.S. and Ni, J. (2016), "Land rental development via institutional innovation in rural Jiangsu, China", Food Policy, Vol. 59, pp. 1-11.

Jiang, S., Wang, J.H., Zhao, Y., Shang, Y.Z., Gao, X.R., Li, H.L., Wang, Q.M. and Zhu, Y.N. (2017), "Sustainability of water resources for agriculture considering grain production, trade and consumption in China from 2004 to 2013”, Journal of Clear Production, Vol. 149, pp. 1210-1218.

Jiao, X.Q., Lyu, Y., Wu, X.B., Li, H.G., Cheng, L.Y., Zhang, C.C., Yuan, L.X., Jiang, R.F., Jiang, B.W., Rengel, Z., Zhang, F.S., Davies, W.J. and Shen, J.B. (2016), "Grain production versus resource and environmental costs: towards increasing sustainability of nutrient use in China", Journal of Experimental Botany, Vol. 67 No. 17, pp. 4935-4949.

Jin, S.Q. and Deininger, K. (2009), "Land rental markets in the process of rural structural transformation: productivity and equity impacts from China", Journal of Comparative Economics, Vol. 37 No. 4, pp. 629-646.

Jin, S.Q. and Jayne, T.S. (2013), "Land rental markets in Kenya: implications for efficiency, equity, household income and poverty", Land Economics, Vol. 89 No. 2, pp. 246-271.

Kung, J.K. (2002), "Off-farm labor markets and the emergence of land rental markets in rural China", Journal of Comparative Economics, Vol. 30 No. 2, pp. 395-414.

Levitt, S.D. (1997), "Using electoral cycles in police hiring to estimate the effect of police on crime", The American Economic Review, Vol. 87 No. 3, pp. 270-290.

Li, L. and Gao, Y. (2013), "Research on the impact of non-food land circulation on food security in China”, Journal of Neijiang Normal University, Vol. 28 No. 6, pp. $44-48$ (in Chinese).

Li, T., Zhao, Y. and Xin, X. (2009), "An analysis on essential characteristics and influencing factors of current farmland transfer", Chinese Rural Economy, No. 10, pp. 4-11 (in Chinese).

Li, T.T., Long, H.L., Zhang, Y.N., Tu, S.S., Ge, D.Z., Li, Y.R. and Hu, B.Q. (2017), “Analysis of the spatial mismatch of grain production and farmland resources in China based on the potential crop rotation system", Land Use Policy, Vol. 60, pp. 26-36. 
CAER 10,2

Liu, Y.S., Yan, R., Long, H.L., Gao, J. and Wang, J.Y. (2014), "Implications of land-use change in rural China: a case study of Yucheng, Shandong province", Land Use Policy, Vol. 40, pp. 111-118.

Lohmar, B., Zhang, Z.X. and Somwaru, A. (2001), "Land rental market development and agricultural production in China", Annual Meetings of the American Agricultural Economics Association, Chicago, IL, August 5-8.

Ma, X.L., Heerink, N., Feng, S.Y. and Shi, X.P. (2017), "Land tenure security and technical efficiency: new insights from a case study in Northwest China", Environment and Development Economics, Vol. 22, pp. 305-327.

Masterson, T. (2007), "Land rental and sales markets in Paraguay”, Working Paper No. 419, The Levy Economics Institute Working Paper Collection, Annandale-on-Huson, New York, NY.

Ministry of Agriculture of the People's Republic of China (2016), "Reply to the suggestion number 1392 in fourth meeting of the 12th National People's Congress (NPC)", available at: www.moa.gov.cn/ zwllm/tzgg/tz/201608/t20160822_5249449.htm (accessed August 15, 2016).

Muraoka, R., Jin, S.Q. and Jayne, T.S. (2015), "Land access, land rental and food security: evidence from Kenya", Proceedings of the 29th International Conference of Agricultural Economics, Milan, August 8-14.

National Bureau of Statistics of the People's Republic of China (2015), "A statement of grain yield in 2015 from National Bureau of statistics of the people's Republic of China", available at: www.stats.gov.cn/tjsj/zxfb/201512/t20151208_1286449.html (accessed August 15, 2016).

Nguyen, T.T., Tchetgen, E.J.T., Kawachi, I., Gilman, S.E., Walter, S., Liu, S.Y., Manly, J.J. and Glymour, M.M. (2016), "Instrumental variable approaches to identifying the casual effect of educational attainment on dementia risk", Annals of Epidemiology, Vol. 26 No. 1, pp. 71-76.

Otsuka, K. (2007), "Efficiency and equity effects of land markets", in Evenson, R. and Pingali, P. (Eds), Handbook of Agricultural Economics, Vol. 3, North-Holland, Amsterdam, pp. 2671-2703.

Otsuka, K., Liu, Y.Y. and Yamauchi, F. (2016), "The future of small farms in Asia”, Development Policy Review, Vol. 34 No. 3, pp. 441-461.

Pašakarnis, G. and Maliene, V. (2010), "Towards sustainable rural development in central and eastern Europe: applying land consolidation", Land Use Policy, Vol. 27 No. 2, pp. 545-549.

Perelman, M.J. (1972), "Farming with petroleum”, Environment: Science and Policy for Sustainable Development, Vol. 14 No. 8, pp. 8-13.

Rada, N., Wang, C.G. and Qin, L.J. (2015), "Subsidy or market reform? Rethinking China's farm consolidation strategy", Food Policy, Vol. 57, pp. 93-103.

Ruseski, J.E., Humphreys, B.R., Hallman, K., Wicker, P. and Breuer, C. (2014), "Sport participation and subjective well-being: instrumental variable results from German survey data", Journal of Physical Activity \& Health, Vol. 11 No. 2, pp. 396-403.

Satyanath, S. and Sergenti, E. (2004), "Economic shocks and civil conflict: an instrumental variables approach", Journal of Political Economy, Vol. 112 No. 4, pp. 725-753.

Stock, J.H., Wright, J.H. and Yogo, M. (2002), "A survey of weak instruments and weak identification in generalized method of moments", Journal of Business and Economic Statistics, Vol. 20 No. 4, pp. 518-529.

Tan, S.H., Heerink, N. and Qu, F.T. (2006), "Land fragmentation and its driving forces in China”, Land Use Policy, Vol. 23, pp. 272-285.

Tan, S.H., Heerink, N., Kruseman, G. and Qu, F.T. (2008), "Do fragmented landholdings have higher production costs? Evidence from rice farmers in Northeastern Jiangxi province, P.R. China", China Economic Review, Vol. 19 No. 3, pp. 347-358. 
Unnevehr, L. and Hoffmann, V. (2015), "Food safety management and regulation: international experiences and lessons for China", Journal of Integrative Agriculture, Vol. 14 No. 11, pp. 2218-2230.

Wang, Y.B., Wu, P.T. and Sun, S.K. (2015), "Comparison of volumetric and stress-weighted water footprint of grain products in China", Ecological Indicators, Vol. 48, pp. 324-333.

Wang, J.Y., Chen, K.Z., Gupta, S.D. and Huang, Z. (2015), "Is small still beautiful? A comparative study of rice farm size and productivity in China and India", China Agricultural Economic Review, Vol. 7 No. 3, pp. 484-509.

Wang, X.L., Chen, Y.Q., Sui, P., Yan, P., Yang, X.L. and Gao, W.S. (2017), "Preliminary analysis on economic and environmental consequences of grain production on different farm sizes in North China Plain”, Agricultural Systems, Vol. 153, pp. 181-189.

Wu, B. (2015a), "Current situation and countermeasures of the agricultural information resource industrialization in western area", Agriculture Network Information, No. 3, pp. 14-17 (in Chinese).

Wu, T.L. (2015b), "Impact of non-agricultural trend of income and scale-based land operation on the grain production technology efficiency of farmer households- taking corn production of farmer households in Hebei province as an example”, Science \& Technology and Economy, Vol. 28 No. 4, pp. 46-50 (in Chinese).

Yan, X.H. and Huo, X.X. (2016), "Drivers of household entry and intensity in land rental market in rural China- evidence from north Henan province", China Agricultural Economic Review, Vol. 8 No. 2 , pp. 345-364.

Yan, X.H., Bauer, S. and Huo, X.X. (2014), "Farm size, land reallocation, and labour migration in rural China", Population, Space and Place, Vol. 20 No. 4, pp. 303-315.

Yi, X.Y. and Cheng, Y.J. (2010), "Analysis on influence factors of households' renting in farmland, and planting behavior and scale of non-grain crops", China Rural Survey, Vol. 6, pp. 2-10 (in Chinese).

Yuan, H.X., Sun, J.W., Yang, W.X., Xing, X.P., Wang, Z.Y., Riley lan, T. and Li, H.L. (2010), "New pathotypes of Heterodera avenae (cereal cyst nematode) from winter wheat in Zhengzhou, Henan China", Australasian Plant Pathology, Vol. 39 No. 2, pp. 107-111.

Zhang, Q.F. (2008), "Retreat from equality or advance towards efficiency? Land markets and inequality in rural Zhejiang", The China Quarterly, Vol. 195 No. 195, pp. 535-557.

Zhang, O.X. (2016), "Research of countermeasures of preventing circulation-land 'non-grain' under the perspective of peasant households differentiation", Academic Journal of Zhongzhou, No. 4, pp. 49-54 (in Chinese).

Zhang, B.B. and Lu, W.J. (2016), "Highway traffic performance and the development of service industry: employment effects of the national trunk highways in western China", Finance \& Trade Economics, Vol. 37 No. 5, pp. 131-145 (in Chinese).

Zhang, O.X. and Jiang, C.Y. (2016), "Analysis on differences of 'non-grain' of different types farmers in transfer-in farmland”, Finance and Trade Research, No. 4, pp. 24-31, 67 (in Chinese).

Zhang, Z.Y. and Du, Z.X. (2015), "Dose land transfer must lead to non-grain crop planting? An empirical analysis based on test data from 1740 planting family farms of countrywide", Economic Perspectives, No. 9, pp. $63-69$ (in Chinese).

Zhang, F.S., Cui, Z.L. and Zhang, W.F. (2014), "Managing nutriment for both food security and environmental sustainability in China: an experiment for the world", Frontiers of Agricultural Science and Engineering, Vol. 1 No. 1, pp. 53-61.

Zhang, Q., Qu, X.T. and Wei, C. (2014), "A study of 'non-grain production' of family farms in the background of grain security", Southeast Academic Research, No. 3, pp. 94-100, 247 (in Chinese).

Zhang, X.H., Zhang, R., Wu, J., Zhang, Y.Z., Lin, L.L., Deng, S.H., Li, L., Yang, G., Yu, X.Y., Qi, H. and Peng, H. (2016), "An emergy evaluation of the sustainability of Chinese crop production system during 2000-2010", Ecological Indicators, Vol. 60 No. 4, pp. 622-633. 
CAER

10,2

292
Zhao, X.F., Zheng, Y.Q., Huang, X.J., Kwan, M.P. and Zhao, Y.T. (2017), "The effect of urbanization and farmland transfer on the spatial patterns of non-grain farmland in China”, Sustainability, Vol. 9 No. 8, pp. 1438, doi: 10.3390/su9081438.

Zhuo, L., Mekonnen, M.M. and Hoekstra, A.Y. (2016), "Consumptive water footprint and virtual water trade scenarios for China - with a focus on crop production, consumption and trade", Environment International, Vol. 94, pp. 211-223.

Zuo, Y.H., Ma, L., Cai, H.L., Wu, T.L. and Xin, X. (2015), “China's on-gong debates over large-scale farming: what are the pros and cons?", China Agricultural Economic Review, Vol. 7 No. 3, pp. 338-343.

\section{Corresponding author}

Zhibiao Nan can be contacted at: zhibiao@1zu.edu.cn 